УДК 004.4; 004.8

\section{ПРИХОВАНІ МОЖЛИВОСТІ МАТЕМАТИКИ ПРИ ОПРАЦЮВАННІ НЕЧІТКОЇ ІНФОРМАЦІї}

ЗАЯЦЬ В.М., РИБИЦЬКА О.М., ЗАЯЦЬ М.М.

Для розв'язання прикладних задач обробки статистичної інформації пропонується застосовувати теорію нечітких інтегралів та розмитої логіки. Розроблені підходи забезпечують вдалий вибір функції належності, критерію правдоподібності та нечіткої міри на основі знань та інтуїції експерта. Обгрунтовується доцільність використання декларативних мов програмування для обробки статистичної інформації. Застосування цих підходів ілюструється конкретними прикладами. Вказуються напрями подальшого використання отриманих результатів.

Ключові слова нечітка множина; функція належності, лінгвістична змінна, база нечітких знань, нечітка логіка. Key words: software, artificial intelligence, declarative programming language, frames, Lisp, Prolog, universal modeling language.

\section{1. Вступ}

Проблеми математичного і комп'ютерного моделювання на сьогодні полягають, зокрема, в незастосовності чіткої логіки та моделей задач із чітко визначеними вхідними параметрами у випадках, коли 3 якихось причин наявні протиріччя, невизначеність або нечіткість інформації про досліджуваний об'єкт, систему чи явище [1].

Невизначеність, як відомо, виникає через недостатність знань, які стосуються конкретної події [2]. Вона присутня до проведення експерименту. Математична модель невизначеності грунтується на теорії ймовірностей, теорії можливостей, мір довіри та ряді інших.

Феномен нечіткості виникає в процесі об'єднання в одне ціле $X$ об'єктів, які мають спільну властивість $\varphi$ :

$$
X=\{x \mid x \text { володіє } \varphi\},
$$

де $X$ пробігає всі елементи деякої універсальної множини.

Зважаючи на те, що в реальності завжди є елементи $x$, для яких неясно, чи мають вони вказану властивість, чи ні, $X$ не $\epsilon$ множиною в класичному розумінні. Всяка спроба трактувати загальний опис призводить до нечітких понять, оскільки точний опис містить надлишок деталей. Збільшення точності у описі веде до збільшення кількості інформації, змістовність якої зменшується до того моменту, поки точність і змістовність не стають взаємовиключними. Про необхідність нечіткості для передачі змістовної інформації вперше наголосив Л.А. Заде [3] . Саме ідеї цього американського вченого зробили поштовх для розвитку «нечіткої математики» [4], яка поряд 3 апаратом нечітких множин містить інші прийоми роботи 3 невизначеністю.

Застосування теорії нечітких множин та мір - це крок на шляху до зближення точності класичної математики 3 наповненим неточністю навколишнім середовищем, спроба подолати лінгвістичний бар'єр між людиною, судження і оцінки якої є наближеними та нечіткими, і технічними засобами, які можуть виконувати тільки чіткі інструкції [5].

\section{2. Особливості застосування Fuzzy-технологій до побудови експертних систем}

Апаратом, який дозволяє працювати із нечіткою логікою, «розмитими» параметрами моделей, $\epsilon$ апарат Fuzzy-технологій. Підрозділом Fuzzyтехнологій є нечіткі експертні системи.

Системи нечіткого виводу призначені для реалізації процесу нечіткого виводу і служать концептуальним базисом всієї сучасної нечіткої логіки. Системи нечіткого виводу дозволяють вирішувати завдання автоматичного управління, класифікації даних, розпізнавання образів, ухвалення рішень i багато інших.

Лінгвістичні змінні розширюють можливості представлення знань. Їх визначають через нечіткі множини, значення яких встановлюються функціями належності. Функції належності можна одержати через оцінки експертів [6] або шляхом аналізу нечітких кластерів. Згідно 3 [6] нечіткі експертні системи можуть бути втілені в життя, коли вартість отримання точної інформації, тобто інформації в абсолютному вимірі, перевищує максимальний дохід від реструктуризації моделі або є практично неможливою.

Відомо, що первісний етап побудови штучного інтелекту на засадах використання природної мови базується на двозначній логіці та механізмі виведення із жорсткими правилами. Експертні системи першого покоління працюють за таким набором правил:

$$
\begin{gathered}
\text { Якщо } X \text { належить } A_{k}, \text { тодi } Y \text { належить } \\
\qquad C_{k} \text {, де } k=\overline{1, N} .
\end{gathered}
$$


Тут $A_{k}$ i $C_{k} \in$ набором точних числових або символічних значень, які можуть бути лінгвістичними значеннями лінгвістичних змінних.

На сучасному етапі в експертних системах для представлення знань найбільш вживаним формалізмом є продукційні моделі

\section{«Якщзо A, тодi B» .}

Друге покоління експертних систем має принаймні дві особливості: нечітке подання знань та нечітке виведення. Одну з найтиповіших задач логічного виведення за умов нечіткості можна сформулювати так

Дано (нечітке) продукиійне правило "Якщо А, то B".

Спостерігається A' ( $A$ в певній мірі). Яким повинно бути $B$ ?

Після отримання нечіткої множини висновків знаходять конкретний числовий відповідник (проводять дефаззифікацію).

\section{3. Побудови моделей з розмитою логікою}

Розглянемо об'єкт з одним виходом і $n$ входами типу

$$
y=f\left(x_{1}, x_{2}, \ldots, x_{n}\right),
$$

де $x_{1}, \ldots, x_{n}-$ набір значень вхідних змінних; $y-$ вихідна змінна.

Для побудови математичної моделі на засадах встановлення взаємозв'язку між вхідними і вихідними змінними згідно 3 експериментальними даними, шляхом проведення операції фаззифікації, кількісні і якісні змінні переводять у лінгвістичні терми:

$$
\begin{gathered}
U_{i}=\left[\underline{u_{i}}, \overline{u_{i}}\right], \quad i=\overline{1, n}, \\
Y=[\underline{y}, \bar{y}],
\end{gathered}
$$

де $\underline{u_{i}}, \overline{u_{i}}$ - найменше та найбільше можливе значення змінної величини $x_{i} ; \underline{y}, \bar{y}$ - найменше та найбільше можливе значення вихідної змінної $y$.

Для розв'язання поставленої задачі (1) необхідно застосувати методику прийняття рішення, за допомогою якої фіксованому вектору вхідних змінних $\mathrm{x}^{*}=\left(\mathrm{x}_{1}^{*}, \mathrm{x}_{2}^{*}, \ldots, \mathrm{x}_{\mathrm{n}}^{*}\right), \mathrm{x}_{\mathrm{i}}^{*} \in \mathrm{U}_{\mathrm{i}}$ однозначно ставився б у відповідність розв'язок y $^{*} \in \mathrm{Y}$. Для формального встановлення такої залежності будемо розглядати вхідні $x_{i}, i=\overline{1, n}$ та вихідний $y$ параметри як лінгвістичні змінні, задані на універсальних множинах (2), (3). Для оцінки лінгвістичних змін- них $\mathrm{x}_{\mathrm{i}}, \mathrm{i}=\overline{1, \mathrm{n}}$ та $y$ будемо використовувати якісні терми $з$ таких терм-множин:

$A_{i}=\left\{a_{i}^{1}, a_{i}^{2}, \ldots, a_{i}^{p_{i}}\right\}-$ терм-множина вхідної змінної $\mathrm{x}_{\mathrm{i}}, \mathrm{i}=\overline{1, \mathrm{n}} ; \mathrm{D}=\left\{\mathrm{d}_{1}, \mathrm{~d}_{2}, \ldots, \mathrm{d}_{\mathrm{m}}\right\}-$ терм-множина вихідної змінної $y$. Для побудови терм - множин можна застосувати, наприклад, методику, запропоновану в [7].

Для кожного терма кожної лінгвістичної змінної на основі знань експерта будують функції належності $\mu^{a_{i}^{p}}(x)$ та $\mu^{d_{j}}(y)$ (трапецієподібні, трикутні тощо [5]), де $\mu^{a_{i}^{p}}(x)$ - міра належності елемента $x \in U_{i} \quad$ до $\quad$ терму $a_{i}^{p} \in A_{i}, \quad i=\overline{1, n} ; p=\overline{1, p_{i}}$; $\mu^{d_{j}}(y)$ - міра належності елемента $y \in Y$ до теpмy $d_{j} \in D, j=\overline{1, m}$.

Визначення лінгвістичних оцінок змінних і необхідних для їх формалізації функцій належності $€$ першим етапом побудови нечіткої моделі досліджуваного об'єкта. У літературі з нечіткої логіки він одержав назву фаззифікації змінних (англ. fuzzification) [8].

Наступним кроком є створення бази нечітких знань.

\section{4. Підхід до побудови моделей баз нечітких знань}

Нехай для об'єкта (1) відомо $N$ правил, які пов'язують його входи й вихід за допомогою векторів типу:

$$
V_{k}=\left(x_{1}, x_{2}, \ldots, x_{n}, y\right), \quad k=\overline{1, N},
$$

причому $\mathrm{N}=\mathrm{k}_{1}+\ldots .+\mathrm{k}_{\mathrm{j}}+\ldots+\mathrm{k}_{\mathrm{m}}$,

де $\mathrm{k}_{\mathrm{j}}$ - кількість експериментальних даних, що відповідають однаковому значенню $d_{j}$ терммножини вихідної змінної $y$; $m$ - загальна кількість термів вихідної змінної, причому в загальному випадку $\mathrm{k}_{1} \neq \ldots \neq \mathrm{k}_{\mathrm{m}}$.

Згідно $з$ принципом моделювання, вказаним в [9], вважатимемо, що $N<p_{1} p_{2} \ldots p_{n}$, тобто кількість наявних експериментальних даних менша повного перебору різних комбінацій можливих термів вхідних змінних $p_{i}, i=\overline{1, n}$. Тоді база знань - це таблиця, сформована за такими правилами: 
1. Розмірність таблиці дорівнює $N \times(n+2)$, у якій $\mathrm{n}+2$ - кількість стовпців, а $\mathrm{N}$ - кількість рядків.

2. Кожен рядок матриці - це комбінація вхідних змінних, віднесених експертом до одного з можливих значень терм-множини вихідної змінної $y$.

При цьому перші $k_{1}$ рядків відповідають значенню вихідної змінної $y=d_{1}$, наступні $k_{2}$ рядки - значенню $y=d_{2}$, а останні $k_{m}$ рядків - значенню $y=d_{m}$;

3. Перші $n$ стовпців матриці відповідають вхідним змінним $x_{i}, i=\overline{1, n} ; \quad(n+1)$-й - вага правила $\mathrm{W}_{\mathrm{jp}}, \mathrm{j}=\overline{1, \mathrm{~m}}, \mathrm{p}=\overline{1, \mathrm{k}_{\mathrm{j}}}, \quad \mathrm{a}(n+2)$-й - значенням $d_{j}$ вихідної терм-множини змінної $y, j=\overline{1, m}$, які відповідають комбінації значень у перших $(n+1)$ стовпцях.

4. Елемент $a_{i}^{j p}$, що знаходиться на перетині $i$-го стовпця та jp-го рядка, відповідає лінгвістичній оцінці параметра $x_{i}$ в рядку матриці знань 3 номером jp. При цьому лінгвістичну оцінку $a_{i}^{j p}$ вибирають із терм-множини, що відповідає змінній $x_{i}$, тобто $a_{i}^{j p} \in A_{i}, i=\overline{1, n} ; j=\overline{1, m} ; p=\overline{1, k_{j}}$.

При формуванні експертом лінгвістичних правил типу «ЯКЩО - ТОДІ», які утворюють базу нечітких знань про певний об'єкт, впевненість експерта в кожному правилі може бути різною. Якщо одне правило на думку експерта може слугувати як безперечна істина, то стосовно іншого правила в того ж експерта можуть бути деякі сумніви.

3 метою відображення цих різних ступенів впевненості в базу нечітких знань вводяться ваги правил - це числа 3 інтервалу $[0,1]$, що характеризують впевненість експерта в кожному вибраному ним конкретному правилі для прийняття рішення. Загальний вигляд бази знань наведено в табл. 1.

Після побудови бази знань необхідно ретельно перевірити у табл. 1 наявність протилежних за змістом рядків, тобто правил, що за однакових вхідних змінних мають різні вихідні значення. Введена матриця знань визначає систему логічних висловлювань типу «ЯКЩО - ТОДІ, ІНАКШЕ», які пов'язують значення вхідних змінних $x_{1}, \ldots, x_{n} 3$ одним із можливих значень виходу $\mathrm{d}_{\mathrm{j}}, \mathrm{j}=\overline{1, \mathrm{~m}}$ :
Таблиця 1. Загальний вигляд бази нечітких знань

\begin{tabular}{|c|c|c|c|c|c|c|}
\hline \multirow{2}{*}{$\begin{array}{l}\text { Но- } \\
\text { мер } \\
\text { вхі- } \\
\text { дної } \\
\text { ком- } \\
\text { бі- } \\
\text { нації } \\
\end{array}$} & \multicolumn{4}{|c|}{ Вхідні змінні } & \multirow{2}{*}{$\begin{array}{l}\text { Вага } \\
w \\
w\end{array}$} & \multirow{2}{*}{ 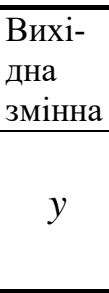 } \\
\hline & $x_{1}$ & $x_{2}$ & $\ldots X_{i} \ldots$ & $x_{n}$ & & \\
\hline 11 & $a_{1}^{11}$ & $a_{2}^{11}$ & $a_{i}^{11}$ & $a_{n}^{11}$ & $w_{11}$ & \multirow{4}{*}{$d_{1}$} \\
\hline 12 & $a_{1}^{12}$ & $a_{2}^{12}$ & $a_{i}^{12}$ & $a_{n}^{12}$ & $w_{12}$ & \\
\hline$\ldots$ & $\ldots$ & $\ldots$ & $\ldots$ & $\ldots$ & $\ldots$ & \\
\hline $1 k_{1}$ & $a_{1}^{1 k_{1}}$ & $a_{2}^{1 k_{1}}$ & $a_{i}^{1 k_{1}}$ & $a_{n}^{1 k_{1}}$ & $W_{1 k_{1}}$ & \\
\hline$\ldots$ & $\ldots$ & $\ldots$ & $\ldots$ & $\ldots$ & $\ldots$ & $\ldots$ \\
\hline$j_{1}$ & $a_{1}^{j 1}$ & $a_{2}^{j 1}$ & $a_{i}^{j 1}$ & $a_{n}^{j 1}$ & $w_{j 1}$ & \multirow{4}{*}{$d_{j}$} \\
\hline$j_{2}$ & $a_{1}^{j 2}$ & $a_{2}^{j 2}$ & $a_{i}^{j 2}$ & $a_{n}^{j 2}$ & $w_{j 2}$ & \\
\hline$\ldots$ & $\ldots$ & $\ldots$ & $\ldots$ & $\ldots$ & $\ldots$ & \\
\hline$j k_{j}$ & $a_{1}^{j k_{j}}$ & $a_{2}^{j k_{j}}$ & $a_{i}^{j k_{j}}$ & $a_{n}^{j k_{j}}$ & $w_{j k_{j}}$ & \\
\hline. & $\ldots$ & $\ldots$ & $\ldots$ & $\ldots$ & $\ldots$ & 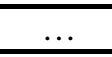 \\
\hline$m_{1}$ & $a_{1}^{m 1}$ & $a_{2}^{m 1}$ & $a_{i}^{m 1}$ & $a_{n}^{m 1}$ & $w_{m 1}$ & \multirow{4}{*}{$d_{m}$} \\
\hline$m_{2}$ & $a_{1}^{m 2}$ & $a_{2}^{m 2}$ & $a_{i}^{m 2}$ & $a_{n}^{m 2}$ & $w_{m 2}$ & \\
\hline. & $\ldots$ & $\ldots$ & $\ldots$ & $\ldots$ & $\ldots$ & \\
\hline$m k_{m}$ & $a_{1}^{m k_{m}}$ & $a_{2}^{m k_{m}}$ & $a_{i}^{m k_{m}}$ & $a_{n}^{m k_{m}}$ & $w_{m k_{m}}$ & \\
\hline
\end{tabular}

ЯКЩО $\left(\mathrm{x}_{1}=\mathrm{a}_{1}^{11}\right)$ I $\left(\mathrm{x}_{2}=\mathrm{a}_{2}^{11}\right) \mathbf{I} \ldots \mathbf{I}\left(\mathrm{x}_{\mathrm{n}}=\mathrm{a}_{\mathrm{n}}^{11}\right)$ (з вагою $\left.w_{11}\right)$,

$$
\text { АБО }\left(\mathrm{x}_{1}=\mathrm{a}_{1}^{12}\right) \mathbf{I}\left(\mathrm{x}_{2}=\mathrm{a}_{2}^{12}\right) \mathbf{I} \ldots \mathbf{I}\left(\mathrm{x}_{\mathrm{n}}=\mathrm{a}_{\mathrm{n}}^{12}\right)(3
$$

вагою $\left.w_{12}\right)$,

$$
\text { АБО }\left(\mathrm{x}_{1}=\mathrm{a}_{1}^{1 \mathrm{k}_{1}}\right) \mathbf{I}\left(x_{2}=a_{2}^{1 k_{1}}\right) \mathbf{I} . . \mathbf{I}\left(x_{n}=a_{n}^{1 k_{1}}\right)
$$

( 3 вагою $\mathrm{w}_{1 \mathrm{k}_{1}}$ ),

ТОДІ $\mathrm{y}=\mathrm{d}_{1}$, ІНАКШЕ

$$
\text { ЯКЩО }\left(\mathrm{x}_{1}=\mathrm{a}_{1}^{21}\right) \mathbf{I}\left(\mathrm{x}_{2}=\mathrm{a}_{2}^{21}\right) \mathbf{I} \ldots \mathbf{I}\left(\mathrm{x}_{\mathrm{n}}=\mathrm{a}_{\mathrm{n}}^{21}\right) \text { (3 }
$$

вагою $\left.w_{21}\right)$,

АБО ...

$$
\text { АБО }\left(\mathrm{x}_{1}=\mathrm{a}_{1}^{2 \mathrm{k}_{2}}\right) \mathbf{I}\left(x_{2}=a_{2}^{2 k_{2}}\right) \mathbf{I} \ldots \mathbf{I}
$$

$\left(x_{n}=a_{n}^{2 k_{2}}\right)$ (з вагою $\left.w_{2 k_{2}}\right)$,

ТОДІ $y=d_{2}$, ІНАКШЕ ...

ЯКЩО $\left(x_{1}=a_{1}^{m 1}\right) \mathbf{I}\left(\mathrm{x}_{2}=\mathrm{a}_{2}^{\mathrm{m} 1}\right) \mathbf{I} \ldots \mathbf{I}\left(x_{n}=a_{n}^{m 1}\right)$

(з вагою $w_{m 1}$ ),

АБО ... 


$$
\begin{gathered}
\text { АБО }\left(\mathrm{x}_{1}=\mathrm{a}_{1}^{\mathrm{mk}_{\mathrm{m}}}\right) \mathbf{I}\left(\mathrm{x}_{2}=\mathrm{a}_{2}^{\mathrm{mk}_{\mathrm{m}}}\right) \mathbf{I} \ldots \mathbf{I} \\
\left.\left(x_{n}=a_{n}^{m k_{m}}\right) \text { (з вагою } w_{m k_{m}}\right), \\
\text { ТОДІ у }=\mathrm{d}_{\mathrm{m}} .
\end{gathered}
$$

Подібну систему логічних висловлювань називають нечіткою базою знань. Із використанням операцій U (АБО) й I (I) описана система логічних висловлювань може бути переписана в більш компактному вигляді:

$$
\bigcup_{p=1}^{k}\left[l_{i=1}^{n}\left(x_{i}=a_{i}^{j p}\right)\right] \rightarrow y=d_{j}, j=\overline{1, m} .
$$

Таким чином, вхідне співвідношення (1), що встановлює зв'язок між вхідними параметрами $x_{i}, i=\overline{1, n}$ та вихідною змінною $y$, формалізовано у вигляді системи нечітких логічних висловлювань (5), що базується на створеній матриці знань. Правила описаної системи нечіткого виведення, у яких ступінь істинності відмінний від нуля, вважають активними.

У роботі [10] було запропоновано метод, що полягає у використанні нечітких логічних рівнянь, які будуються на основі матриці знань або ізоморфної до неї системи логічних висловлювань (5) і дозволяють обчислювати значення функцій належності вихідної змінної за фіксованих значень входів об'єкта.

Лінгвістичні оцінки $\mathrm{a}_{\mathrm{i}}^{\mathrm{jp}}$ змінних $\mathrm{x}_{1}, \ldots \mathrm{x}_{\mathrm{n}}$, що входять у логічні висловлювання (5), будемо розглядати як нечіткі множини, визначені на універсальних множинах (2). Введемо такі позначення: $\mu^{a_{\mathrm{i}}^{\mathrm{jp}}}\left(\mathrm{x}_{\mathrm{i}}\right)-$ функція належності параметра $x_{i}$ до нечіткого терму $a_{i}^{j p}, i=\overline{1, n}, j=\overline{1, m, p}=\overline{1, k_{j}}$; $\mu^{\mathrm{d} j}\left(\mathrm{x}_{1}, \mathrm{x}_{2}, \ldots \mathrm{x}_{\mathrm{n}}\right)$ - функція належності вектора вхідних змінних $\mathrm{x}=\left(\mathrm{x}_{1}, \mathrm{x}_{2}, \ldots \mathrm{x}_{\mathrm{n}}\right)$ терму вихідної змінної $\mathrm{y}=\mathrm{d}_{\mathrm{j}}, \mathrm{j}=\overline{1, \mathrm{~m}}$.

Таким чином, у нас наявні два типи функцій, зв'язок між якими визначається базою нечітких знань (5), на основі чого можна вивести систему логічних рівнянь:

$$
\mu^{d_{1}}\left(x_{1}, x_{2}, \ldots x_{n}\right)=w_{11}\left[\mu^{a_{1}^{11}}\left(x_{1}\right) \wedge \mu^{a_{2}^{11}}\left(x_{2}\right) \wedge \ldots \wedge \mu^{a_{n}^{11}}\left(x_{n}\right)\right] \vee
$$

$$
\begin{aligned}
& \vee w_{12}\left[\mu^{a_{1}^{12}}\left(x_{1}\right) \wedge \mu^{a_{2}^{12}}\left(x_{2}\right) \wedge \ldots \wedge \mu^{a_{n}^{12}}\left(x_{n}\right)\right] \vee \\
& \ldots \vee \mathrm{w}_{1 \mathrm{k}_{1}}\left[\mu^{\mathrm{a}_{1}^{1 \mathrm{k}_{1}}}\left(\mathrm{x}_{1}\right) \wedge \mu^{\mathrm{a}_{2}^{1 \mathrm{k}_{1}}}\left(\mathrm{x}_{2}\right) \wedge \ldots \wedge \mu^{\mathrm{a}_{\mathrm{n}}^{1 \mathrm{k}_{1}}}\left(\mathrm{x}_{\mathrm{n}}\right)\right], \\
& \mu^{\mathrm{d}_{2}}\left(\mathrm{x}_{1}, \mathrm{x}_{2}, \ldots \mathrm{x}_{\mathrm{n}}\right)=\mathrm{w}_{21}\left[\mu^{\mathrm{a}_{1}^{21}}\left(\mathrm{x}_{1}\right) \wedge \mu^{\mathrm{a}_{2}^{21}}\left(\mathrm{x}_{2}\right) \wedge \ldots \wedge \mu^{\mathrm{a}_{\mathrm{n}}^{21}}\left(\mathrm{x}_{\mathrm{n}}\right)\right] \vee \\
& \vee w_{22}\left[\mu^{a_{1}^{22}}\left(x_{1}\right) \wedge \mu^{a_{2}^{22}}\left(x_{2}\right) \wedge \ldots \wedge \mu^{a_{n}^{22}}\left(x_{n}\right)\right] \vee \\
& \ldots \vee \mathrm{w}_{2 \mathrm{k}_{2}}\left[\mu^{\mathrm{a}_{1}^{2 \mathrm{k}_{2}}}\left(\mathrm{x}_{1}\right) \wedge \mu^{\mathrm{a}_{2}^{2 \mathrm{k}_{2}}}\left(\mathrm{x}_{2}\right) \wedge \ldots \wedge \mu^{\mathrm{a}_{\mathrm{n}}^{2 \mathrm{k}_{2}}}\left(\mathrm{x}_{\mathrm{n}}\right)\right], \\
& \mu^{d} \mathrm{~m}\left(x_{1}, x_{2}, \ldots x_{n}\right)=w_{m 1}\left[\mu^{a_{1}^{m 1}}\left(x_{1}\right) \wedge \mu^{a_{2}^{m}}\left(x_{2}\right) \wedge \ldots \wedge \mu^{a_{n}^{m 1}}\left(x_{n}\right)\right] \vee \\
& \vee W_{m 2}\left[\mu^{a_{1}^{m 2}}\left(x_{1}\right) \wedge \mu^{a_{2}^{m 2}}\left(x_{2}\right) \wedge \ldots \wedge \mu^{a_{n}^{m 2}}\left(x_{n}\right)\right] \vee \ldots \\
& \ldots \vee W_{m k_{m}}\left[\mu^{a_{1}^{m k_{m}}}\left(x_{1}\right) \wedge \mu^{a_{2}^{m k_{m}}}\left(x_{2}\right) \wedge \ldots \wedge \mu^{a_{n}^{m k_{m}}}\left(x_{n}\right)\right],
\end{aligned}
$$

де $\vee-$ логічне «АБО»; $\wedge$ - логічне «I».

За аналогією з (5), дану систему (6) нечітких логічних рівнянь можна подати в компактнішому вигляді:

$$
\mu^{d_{j}}\left(x_{1}, x_{2}, \ldots, x_{n}\right)=\underset{p=1}{k_{j}}\left(w_{j p}\left[\hat{i=1}^{n} \mu^{a_{i}^{j p}}\left(x_{i}\right)\right]\right), j=\overline{1 . m} .(7)
$$

Прийняття рішення $\mathrm{d}^{*} \in \mathrm{D}\left\{\mathrm{d}_{1}, \mathrm{~d}_{2}, \ldots, \mathrm{d}_{\mathrm{m}}\right\}$, яке відповідає фіксованому вектору значень вхідних змінних $x^{*}=\left(x_{1}^{*}, x_{2}^{*}, \ldots, x_{n}^{*}\right)$, будемо здійснювати відповідно до алгоритму [10], побудованого з використанням апарату нечіткої логіки:

1. Визначається можливий діапазон змінювання контрольованих параметрів, складається база знань з використанням експертних даних та виводиться система нечітких логічних рівнянь (7).

2. Фіксується вектор значень вхідних змінних $x^{*}=\left(x_{1}^{*}, x_{2}^{*}, \ldots, x_{n}^{*}\right)$.

3. Задається вигляд функцій належності нечітких термів для різних контрольованих параметрів.

4. Використовуючи логічні рівняння (7), обчислюються значення багатопараметричних функцій належності $\mu^{\mathrm{dj}_{\mathrm{j}}}\left(\mathrm{x}_{1}^{*}, \mathrm{x}_{2}^{*}, \ldots ., \mathrm{x}_{\mathrm{n}}^{*}\right)$ вектора $\mathrm{X}$ для всіх значень $d_{j}, j=\overline{1, m}$ вихідної змінної $y$. При цьому логічні операції $\vee(\mathbf{A Б О ) ~ и ̆ ~} \wedge$ (I) над функціями належності замінюються на операції $\max$ та min:

$$
\begin{aligned}
& \mu(a) \vee \mu(b)=\max [\mu(a), \mu(b)], \\
& \mu(a) \wedge \mu(b)=\min [\mu(a), \mu(b)] .
\end{aligned}
$$


Отже, спочатку знаходять мінімальні значення функцій належності в кожному правилі, а потім поміж них обирають найбільше значення функції належності серед усіх правил для кожного значення $d_{j}, j=\overline{1, m}$, яке і ставлять у відповідність вихідній змінній $y$. Таким чином робиться висновок про належність вихідної змінної $y$ до терму $d_{j}^{*}$, функція належності якого максимальна.

Запропонований алгоритм використовує ідею ідентифікації лінгвістичного терму за максимумом функції належності та узагальнює цей підхід на всю матрицю знань. Обчислювальна частина даного алгоритму легко реалізується шляхом простого застосування операцій тах та min.

Для одержання чіткого числа з інтервалу $[\underline{y,} \bar{y}]$, що відповідає нечіткому значенню вихідної змінної, необхідно застосувати операцію дефаззифікації. Визначити це чітке число $y^{*}$ можна, наприклад, за методом центру тяжіння:

$$
y^{*}=\frac{\int_{\operatorname{Min}}^{\operatorname{Max}} y \mu(y) d y}{\int_{\operatorname{Min}}^{\operatorname{Max}} \mu(y) d y},
$$

де Min i Max - ліва і права точки інтервалу носія нечіткої множини вихідної змінної $y$.

\section{5. Задача прогнозування вартості товару}

В роботі на основі запропонованого підходу розглянута задача прогнозування вартості нереалізованого товару певного виду на кінець сезону торгівлі торговельної фірми, яка займається препаратами хімічного захисту рослин.

Експертом було встановлено, що вагомими чинниками, які впливають на залишок $Y, \epsilon: x_{1}$ («залишок») - залишок попереднього сезону торгівлі (у доларах США); $x_{2}$ («нові закупки») - вартість нових закупок (у доларах США); $x_{3}$ («націнка») середня величина торговельної націнки (у відсотках); $x_{4}$ («термін») - тривалість продажу даного препарату (у роках). Універсальні множини для описаних змінних визначено такими: $U_{1}=[0 ; 600000] ; \quad U_{2}=[20000 ; 1500000]$; $U_{3}=[0 ; 50] ; U_{4}=[0 ; 10]$. Універсальна множина для прогнозованої величини збігається, очевидно, 3 $U_{1}$.

Для кожної вхідної та вихідної змінних побудовано терм-множини:

$A_{1}=\{"$ малий","середній","великий","критичний" $\}=\{M, C, B, K\}$;

$A_{2}=\{"$ мала","середня","велика" $\}=\{M, C, B\}$;

$A_{3}=\{"$ малий","середній","великий" $\}=\{M, C, B\} ;$

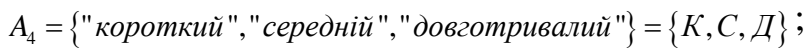

$D=\{"$ малий","середній","великий","критичний" $\}=\{M, C, B, K\}$ •

Виходячи з інформації, наданої експертом, побудовано функції належності для термів вхідних та вихідної змінних (рис.1-4).

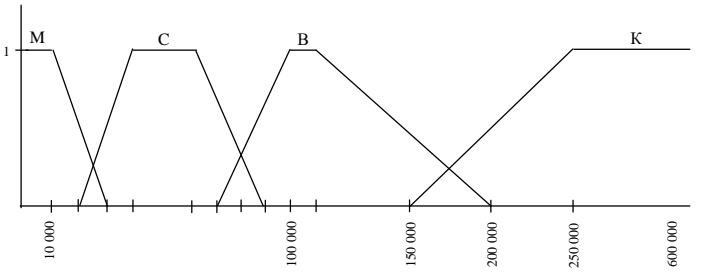

Рис.1 Функція належносі лінгвістичної змінної «залишок»

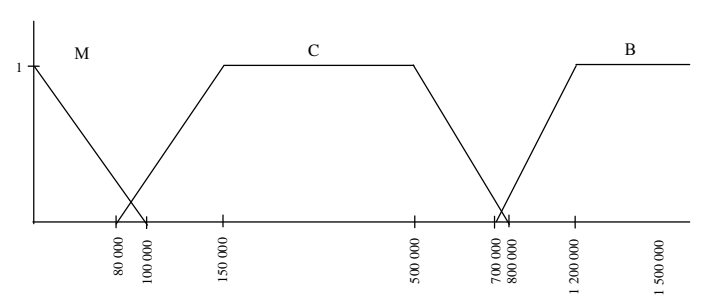

Рис.2. Функція належності лінгвістичної змінної «нові закупки»

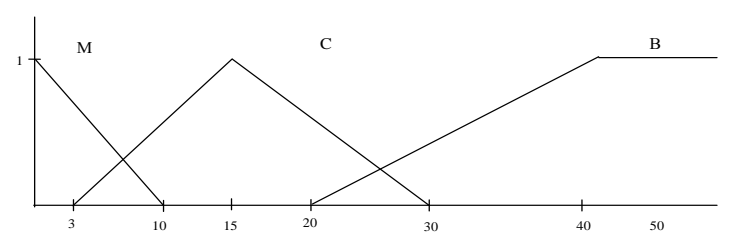

Рис. 3. Функція належності лінгвістичної змінної «націнка»

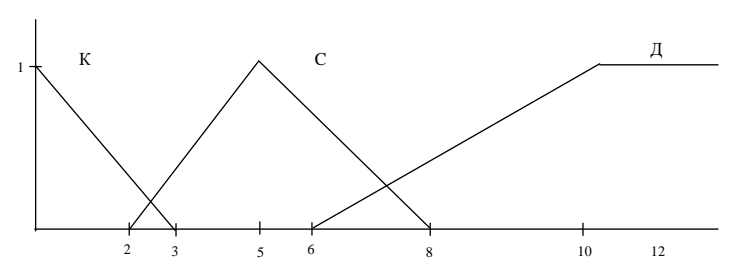

Рис.4. Функція належності лінгвістичної змінної «термін» 
Наступним кроком є побудова бази нечітких знань (табл.2).

Таблиця 2. База нечітких знань задачі

\begin{tabular}{|c|c|c|c|c|c|c|}
\hline \multirow{2}{*}{$\begin{array}{l}\text { Номер } \\
\text { вхід- } \\
\text { ної } \\
\text { ком- } \\
\text { біна- } \\
\text { ції } \\
\text { (логі- } \\
\text { чного } \\
\text { пра- } \\
\text { вила) }\end{array}$} & \multicolumn{4}{|c|}{ Вхідні змінні } & \multirow{2}{*}{$\begin{array}{l}\text { Ba- } \\
\text { га } \\
\\
W\end{array}$} & \multirow{2}{*}{ 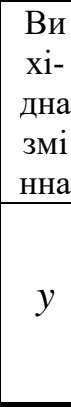 } \\
\hline & $X_{1}$ & $x_{2}$ & $x_{3}$ & $x_{4}$ & & \\
\hline 11 & $M$ & $M$ & M & K & 1 & \multirow{11}{*}{$d_{1}$} \\
\hline 12 & $\mathrm{~B}$ & $\mathrm{M}$ & $\mathrm{M}$ & $\mathrm{C}$ & 0,9 & \\
\hline 13 & $\mathrm{~B}$ & $\mathrm{M}$ & $\mathrm{M}$ & Д & 1 & \\
\hline 14 & $\mathrm{~K}$ & $\mathrm{M}$ & $\mathrm{M}$ & $\mathrm{C}$ & 1 & \\
\hline 15 & $\mathrm{M}$ & $\mathrm{M}$ & $\mathrm{B}$ & Д & 0,7 & \\
\hline 16 & $\mathrm{M}$ & $\mathrm{C}$ & $\mathrm{B}$ & $\mathrm{C}$ & 0,7 & \\
\hline 17 & $\mathrm{C}$ & $\mathrm{M}$ & $\mathrm{C}$ & $\mathrm{C}$ & 0,8 & \\
\hline 18 & $\mathrm{C}$ & $\mathrm{M}$ & $\mathrm{C}$ & Д & 0,8 & \\
\hline 19 & $\mathrm{C}$ & $\mathrm{C}$ & $\mathrm{C}$ & $\mathrm{C}$ & 0,7 & \\
\hline 20 & $\mathrm{~B}$ & $\mathrm{M}$ & $\mathrm{C}$ & Д & 0,9 & \\
\hline 21 & $\mathrm{~B}$ & $\mathrm{M}$ & $\mathrm{B}$ & Д & 0,5 & \\
\hline 23 & $\mathrm{C}$ & $\mathrm{M}$ & $\mathrm{B}$ & Д & 1 & \multirow{6}{*}{$d_{2}$} \\
\hline 24 & $\mathrm{M}$ & $\mathrm{C}$ & $\mathrm{C}$ & $\mathrm{C}$ & 1 & \\
\hline 25 & $\mathrm{M}$ & $\mathrm{B}$ & $\mathrm{B}$ & $\mathrm{C}$ & 0,8 & \\
\hline 26 & $\mathrm{C}$ & $\mathrm{C}$ & $\mathrm{M}$ & $\mathrm{C}$ & 0,8 & \\
\hline 27 & $\mathrm{C}$ & $\mathrm{B}$ & $\mathrm{M}$ & $\mathrm{B}$ & 0,7 & \\
\hline 28 & $\mathrm{C}$ & $\mathrm{B}$ & $\mathrm{C}$ & $\mathrm{C}$ & 0,7 & \\
\hline 29 & $\mathrm{~B}$ & $\mathrm{C}$ & $\mathrm{C}$ & $\mathrm{C}$ & 0,7 & \multirow{8}{*}{$d_{3}$} \\
\hline 30 & $\mathrm{~B}$ & $\mathrm{C}$ & $\mathrm{C}$ & Д & 0,5 & \\
\hline 31 & $\mathrm{~B}$ & $\mathrm{C}$ & $\mathrm{B}$ & Д & 0,3 & \\
\hline 32 & $\mathrm{~K}$ & $\mathrm{C}$ & B & Д & 0,8 & \\
\hline 33 & $\mathrm{M}$ & B & $\mathrm{C}$ & $\mathrm{C}$ & 0,9 & \\
\hline 34 & $\mathrm{M}$ & B & $\mathrm{C}$ & $\mathrm{K}$ & 1 & \\
\hline 35 & $\mathrm{C}$ & $\mathrm{B}$ & $\mathrm{M}$ & $\mathrm{K}$ & 1 & \\
\hline 36 & $\mathrm{C}$ & B & $\mathrm{C}$ & Д & 0,8 & \\
\hline 37 & $\mathrm{M}$ & B & B & $\mathrm{C}$ & 0,8 & \multirow{4}{*}{$d_{4}$} \\
\hline 38 & $\mathrm{M}$ & $B$ & $B$ & Д & 0,9 & \\
\hline 39 & $\mathrm{C}$ & B & B & $\mathrm{C}$ & 0,9 & \\
\hline 40 & $\mathrm{C}$ & B & B & Д & 1 & \\
\hline 41 & B & B & B & Д & 1 & \\
\hline
\end{tabular}

Наступні розрахунки проведено для даних торговельного підприємства за сезон продажів певного року: $x_{1}{ }^{*}=80000 ; x_{2}{ }^{*}=36000 ; x_{3}{ }^{*}=22 ; x_{4}{ }^{*}=9$. У цьому випадку змінна $x_{1}$ належить до термів «середній» (3 мірою належності $\left.\mu(x)=1-\frac{1}{30000}(x-60000)\right)$ або «високий» (із мірою належності $\left.\mu(x)=\frac{1}{30000}(x-70000)\right) ; x_{2}-$ терму «мала» (3 мірою належності $\left.\mu(x)=1-\frac{1}{100000} x\right)$; $x_{3}$ - до термів «середня» (3 мірою належності $\left.\mu(x)=1-\frac{1}{15}(x-15)\right)$ або «висока» (з мірою належності $\left.\mu(x)=\frac{1}{20}(x-20)\right) ; x_{4}$ - до терма «довготривалий» (із мірою належності $\left.\mu(x)=\frac{1}{4}(x-6)\right)$. Простим співставленням легко побачити, що активними будуть правила 18, 20, 21 (приводять до виходу $d_{1}$ ) та 23 (приводить до виходу $\left.d_{2}\right)$.

Із відповідної системи логічних рівнянь одержимо значення $\mu^{d_{1}}$ та $\mu^{d_{2}}$ :

$\mu^{d_{1}}=\max \{0,8 \min \{0,333 ; 0,64 ; 0,53 ; 0,75\} ; 0,9 \min \{0,333 ; 0,64 ; 0,53 ; 0,75\}$; $0,5 \min \{0,333 ; 0,64 ; 0,1 ; 0,75\}\}=\max \{0,2664 ; 0,3 ; 0,05\}=0,3$;

$$
\mu^{d_{2}}=\max \{\min \{0,333 ; 0,64 ; 0,1 ; 0,75\}\}=0,1 .
$$

Після проведення описаних в алгоритмі обчислень одержимо міру належності вихідної змінної:

$$
\mu(w)= \begin{cases}0,3, & \text { якщо } w \in(0 ; 24000) ; \\ 1-\frac{1}{20000}(w-10000), & \text { якщо } w \in(24000 ; 28000) ; \\ 0,1, & \text { якщо } w \in(28000 ; 87000) ; \\ 1-\frac{1}{30000}(w-60000), & \text { якщо } w \in(87000 ; 90000) .\end{cases}
$$

Графік отриманої функції належності зображено на рис.5.

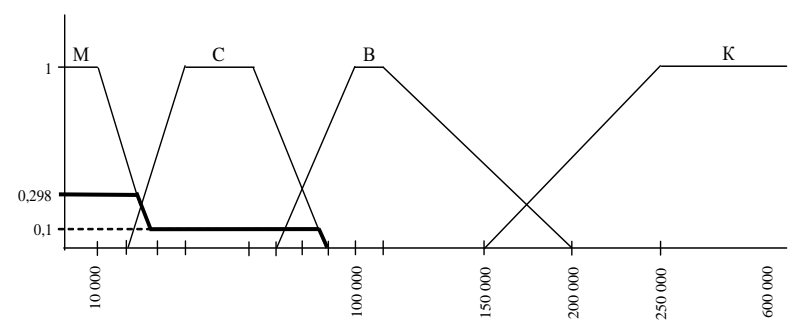

Рис. 5. Графік функції належності вихідної змінної «залишок»

Кількісне значення вихідної величини $y^{*}$ (результат дефаззифікації) обчислимо методом центру тяжіння (10): 


$$
\begin{gathered}
y^{*}=\frac{\int_{\operatorname{Min}}^{\operatorname{Max}} w \mu(w) d w}{\int_{\operatorname{Min}}^{\operatorname{Max}} \mu(w) d w} . \\
\int_{\text {Min }}^{\text {Max }} w \mu(w) d w=\int_{0}^{24000} 0,3 w d w+\int_{24000}^{28000} w\left(1-\frac{1}{20000}(w-10000)\right) d w+ \\
+\int_{28000}^{87000} 0,1 w d w+\int_{87000}^{90000} w\left(1-\frac{1}{30000}(w-60000)\right) d w=172800000+ \\
+1398400+339250000+131999500=353865180 ; \\
\int_{\operatorname{Min}}^{\operatorname{Max}} \mu(w) d w=\int_{0}^{24000} 0,3 d w+\int_{24000}^{28000}\left(1-\frac{1}{20000}(w-10000)\right) d w+ \\
+\int_{28000}^{87000} 0,1 d w+\int_{87000}^{90000}\left(1-\frac{1}{30000}(w-60000)\right) d w=7200+ \\
+800+5500+88,5=13588,5 .
\end{gathered}
$$

Остаточно значення прогнозованої величини залишку товарної маси дорівнює

$$
y^{*}=\frac{353865180}{13588,5} ; 26041,5,
$$

що є достатньо близьким до реального залишку товару на кінець сезону вибраного року, а саме 23200 доларів США.

Слід зауважити, що прогнозовані значення можна пробувати знаходити більш близькими до реально спостережуваних (за декілька попередніх років) шляхом перегляду встановлених вагових коефіцієнтів, коригування функцій належності тощо. Також можна збільшувати кількість вхідних величин. Проте при їх надто великій кількості побудова нечіткої бази знань про невідому залежність стає важким завданням. Це обумовлене тим, що в пам'яті середньої статистичної людини одночасно може утримуватись не більше за $7 \pm 2$ понять-ознак. У таких випадках доцільно проводити класифікацію вхідних змінних і згідно з нею будувати дерево виведення, яке визначає систему вкладених один в одного висловлювань [5].

Можна запропонувати інший підхід до опрацювання великих обсягів нечітких даних за умов неповної визначеності вектора вхідних змінних (первинних ознак). Суть підходу грунтується на проведенні імітаційного моделювання поведінки досліджуваної системи і шляхом експертної оцінки доповнення існуючої бази знань новими інформативними даними та встановлення вектора вхідних ознак. Очевидно, такий підхід є ітераційним і необхідно потурбуватися про збіжність процесу вирахувань для досягнення поставленої мети при мінімальних затратах та обмеженій похибці.

\section{6. Висновки}

Для роботи з нечисловими даними в задачах штучного інтелекту, побудови систем розпізнавання, експертних систем, медичною та параметричною діагностикою, створення логіко-лінгвістичних моделей найбільш вдало пристосовані декларативні мови програмування, які на мові логічних висловлювань та функціонально-логічних залежностей забезпечують можливість опису задачі 3 нечітко формульованими даними і отримання розв'язків у вигляді логічних вислідів, нових функціональних залежностей або імовірнісних характеристик з визначеним математичним сподіванням та дисперсією вхідної ознаки. У кінцевому підсумку має бути сформовано уточнений початковий вектор первинних ознак, який забезпечить достовірне опрацювання нечітких даних.

Отже, опрацювання неповної або нечітко визначеної інформації полягає, з одного боку, у застосуванні теорії розмитої логіки ( зокрема, теорії нечітких множин та мір) та побудові дерева логічного висліду або, з іншого боку, у формуванні логічних правил, що містять функціонально-логічні залежності із невизначеними змінними, які можуть приймати як детерміновані, так і ймовірнісні значення. В процесі опрацювання апріорної інформації та виборі відповідних критеріїв правдоподібності можна поповнювати недостатні дані, забезпечуючи формування нових знань.

Для реалізації відповідних алгоритмів найбільш вдало пристосовані декларативні мови програмування, зокрема Refal, Reduce [11], Matcad [12] мови аналітичних перетворень та системи автоматизації математичних вирахувань, Lisp, Skala [13] аплікативні мови функціонального програмування, Prolog - мова вирахування логічних диз'юнктів та правил [13, 14, 15].

Наведені підходи доцільно застосовувати у тих предметних галузях знань, для яких ускладнений або неможливий аналітичний опис засобами сучасної математики, або вимагаються колосальні технічні затрати і людські ресурси для повноцінного збору інформації про предметну область, зокрема, в галузі медицини, геології, екології, технічної діагностики, розпізнаванні та ідентифікації складно структурованих сигналів, процесів та явищ.

Література: 1. Уэно $X$. Введение в инженерию знаний / Х. Уэно - Токио: Омся, 1985. 2. Новак В. Математические принципы нечеткой логики / В. Новак, И. Перфильева, И. Мочкорж. М: Физмалит, 2006. 347 с. 3. Zadeh L.A. Outline of a New Approach to the Analysis of Complex Systems and Decision Processes”. IEEE. Trans. Syst. Van and Cybern, 1, 1973. Р. 28-44. 4. Конышева Л.К. Основы теории нечетких множеств / Л.К. Конышева, Д.М. Назаров. М: Питер, 2011. 190 с. 5. Сявавко М. Математика прихованих можливостей / М. Сявавко. Острог: Видавництво НУ «Острозька академія», 2011. 394 с. 6. Турксен И.Б. Нечеткие экспертные системы / Под ред. 
М. Желены. СПб: Питер, 2002. 1120 с. 7. Шапиро Д.И., Блищун А.Ф. Выбор решений при нечетком состоянии системы. Алгоритмы и программы, 1978, №1, с.75. 8. Zimmermann H.-J. Fuzzy Set Theory and it's Applications. Kluner Academic Publishers, Dordrecht, Boston, MA, $2^{\text {nd }}$., 1991. 315 р. 9. Дюбуа Д. Теория возможности. Приложения к представлению знаний в информатике / Д. Дюбуа, А. Прад. М.: Радио и связь, 1990. 288 с. 10. Ротштейн О.П. Диференційна діагностика ішемічної хвороби серця на основі нечіткої логіки / Ротштейн О.П., Жупанова М.О., Шеверда В.М. Вісник ВПІ. №3. 1994. С. 32 -38. 11. Еднерал В.Ф. Язык аналитических вычислений REDUCE / В.Ф Еднерал, А.П. Крюков, А.Я. Родионов. М.: Из-во МГУ, 1984. 176 с. 12. Дьяконов В. Matcad 2001 // В. Дьяконов. СПБ: Питер, 2001. 624 с. 13. Заяць В.M. Функційне програмування / В.М. Заяць. Львів.: Бескид Біт, 2003. 160 с. 14. Ц. Ин. Программирование в Турбо-Прологе / Ц. Ин, Д. Соломон. М.: Мир, 1996. 640 с. 15. Заящь В.М. Логічне та функціональне програмування. Навч. посібник. Львів: Українські технології, 2016. 400 c.

Transliterated bibliography:

1. Ujeno $H$. Vvedenie $\mathrm{v}$ inzheneriju znanij / $\mathrm{H}$. Ujeno. Tokio: Omsja, 1985.

2. Novak V. Matematicheskie principy nechetkoj logiki / V. Novak, I. Perfil'eva, I. Mochkorzh. M: Fizmalit, 2006.347 s. 3. Zadeh L.A. Outline of a New Approach to the Analysis of Complex Systems and Decision Processes”. IEEE. Trans. Syst. Van and Cybern, 1, 1973. P. 28-44.

4. Konysheva L.K. Osnovy teorii nechetkih mnozhestv / L.K. Konysheva, D.M. Nazarov. M: Piter, 2011. 190 s.

5. Sjavavko M. Matematika prihovanih mozhlivostej / M. Sjavavko. Ostrog: NU «Ostroz'ka akademija», 2011. 394 s.

6. Turksen I.B. Nechetkie jekspertnye sistemy / Pod red. M. Zheleny. SPb: Piter, 2002. 1120 s.

7. Shapiro D.I., Blishhun A.F. Vybor reshenij pri nechetkom sostojanii sistemy. Algoritmy i programmy, 1978, №1, s.75.

8. Zimmermann H.-J. Fuzzy Set Theory and it's Applications. Kluner Academic Publishers, Dordrecht, Boston, MA, $2^{\text {nd }}$., 1991. $315 \mathrm{p}$.

9. Djubua D. Teorija vozmozhnosti. Prilozhenija k predstavleniju znanij v informatike / D. Djubua, A. Prad. M.: Radio i svjaz', 1990. 288 s.

10. Rotshtejn O.P. Dyferencijna diagnostyka ishemichnoi' hvoroby sercja na osnovi nechitkoi' logiky / Rotshtejn O.P., Zhupanova M.O., Sheverda V.M. Visnyk VPI. №3. 1994. S. 32-38.

11. Edneral V.F. Jazyk analiticheskih vychislenij REDUCE / V.F Edneral, A.P. Krjukov, A.Ja. Rodionov. M.: MGU, 1984. $176 \mathrm{~s}$.

12. D'jakonov V. Matcad 2001 // V. D'jakonov. SPB: Piter, 2001. $624 \mathrm{~s}$.

13. Zajac' V.M. Funkcijne programuvannja / V.M. Zajac'. L'viv.: Beskyd Bit, 2003. $160 \mathrm{~s}$.

14. C. In. Programmirovanie v Turbo-Prologe / C. In, D. Solomon. M.: Mir, 1996. 640 s.

15. Zajac' V.M. Logichne ta funkcional'ne programuvannja. Navch. posibnyk. Gryf nadano MON Ukrai'ny (protokol № 1 vid 03.05.2013 r / V.M. Zajac', M.M. Zajac'. L'viv: Ukrai'ns'ki tehnologii', 2016. 400 s.

Надійшла до редколегії 25.10.2017

Рецензент: д-р фіз.-мат. наук, проф. Калинюк П.І.
Заяць Василь Михайлович, д-р техн. наук, професор Університету Технологічно-Природничого (м. Бидгощ, Польща), професор кафедри обчислювальної техніки Національного університету водного господарства (м. Рівне, Україна). Наукові інтереси: числові методи в прикладних застосуваннях, математичне і комп'ютерне моделювання динамічних систем, розпізнавання об'єктів зі складною динамічною природою, електрорадіотехніка та інформатика. Захоплення і хобі: туризм, велоспорт, театр; щоденні піші прогулянки 7 км. Адреca: Україна, 79070, Львів, пр. Червона Калина, 39 кв. 4, тел.: дом. (+38) (032) 222-43-48; роб.: (+48) 52-340-5330; моб.: $\quad(+38)(032) \quad 0678362473$, e-mail: zvm01@rambler.ru

Рибицька Ольга Мар'янівна, канд. фіз.-мат. наук, доцент кафедри вищої математики НУ «Львівська політехніка». Наукові інтереси: застосування теорії нечітких множин та розмитої логіки до прикладних задач теорії управління та інформатики за галузями знань. Захоплення і хобі: подорожі, театр, література. Адреса: Україна, 79000, Львів, вул. С. Бандери, 23, роб. тел.. 25822 50, дом.: 79038, Львів, вул. Китайська 75-А, тел. (032)2513327, e-mail: olga.rybytska@gmail.com

Заяць Марія Михайлівна, ст. викладач НУ «Львівська політехніка». Наукові інтереси: інформаційні технології, інженерія знань, математичне і комп'ютерне моделювання складних об'єктів, логічне програмування. Захоплення і хобі: туризм, театр, якісне приготування вишуканих страв. Адрес: Україна, 79070, Львів, пр. Червона Калина, 39, кв. 4, тел.: дом. (+38) (032) 222-43-48; роб.: (+38) (032) 258-25-38 моб.: (+38)(032) 0989327526, e-mail: zajacmarija@gmail.com

Zaiatc Vasyl M., DSc.., Professor, Professor University of Science and Technology (m. Bydgoszcz, Poland). My research interests include numerical methods in applied applications, mathematical and computer modeling of dynamic systems, recognition of objects of complex dynamic nature, electro - radiotehnika and informatics. Tastes and hobbies: hiking, biking, theater; daily walks $7 \mathrm{~km}$. Address, phones pin: Ukraine, $79070, \mathrm{~m}$. Lviv, avenue Chervona Kalyna №39 flat 4. Tel .: Home. (38) (032) 222-43-48; Job: (+48) 52-340-53-30; Mob.: (+38) (032) 0678362473.

Rybytska Olga Maryanivna, Ph.D., associate professor, associate professor of the department of higher mathematics, NU "Lviv Polytechnic". Scientific interests: application of the theory of fuzzy sets and blurry logic to applied problems of the theory of management and informatics by branches of knowledge. Address: $79000 \mathrm{~m}$. Lviv, S. Bandera st., 23, work tel. 25822 50, home address: 79038 Lviv, st. Chinese 75-A, house tel. (032) 2513327.

Zaiats Mary M., senior teacher National University "Lviv polytechnic" (Lviv, Ukraine). My research interests include information technology, engineering knowledge, mathematical and computer modeling of complex objects, logic programming. Interests and hobbies: hiking, theater, highquality gourmet food. Address: Ukraine, 79070, m. Lviv, avenue Chervona Kalyna number 39 kv.4. Tel. (38032) 222-43-48; Job.: (+38) (032) 258-25-38 Mob.: (+38) (032) 0989327526. 